\title{
The use of magnetic and ultrasonic structuroscopy for inspection of ADI/AGI castings
}

\section{Zuzana Andršová, Břetislav Skrbek}

Department of Material Science, Faculty of Mechanical Engineering, Technical University of Liberec, Studentska 2, 46117 Liberec 1, zuzana.andrsova1@tul.cz

The Austempered Ductile Iron (ADI) and Austempered Grey Iron (AGI) represent the most progressive group of grafitic irons with reference to mechanical properties. These properties depend on accurate observance of default structure, chemical composition and isothermal hardening conditions. ADI/AGI castings are mostly used in automotive industry for moving parts and safety critical items. The production of ADI/AGI in the Czech Republic is insufficient, even if the automotive is the important member of our industrial production. The NDT can be used as the tool of $\mathbf{1 0 0 \%}$ inspection - that provides constant production quality and could support the production of this promising material. This work deals with the development of inspection procedures based on the magnetic and ultrasonic structuroscopy.

Keywords: austempered iron, ultrasonic structuroscopy, magnetic spot-pole method

\section{Acknowledgement}

This work was supported by SGS project „Innovations in Material Engineering“.

\section{References}

[1] ČSN EN 1564 (42 0960): Slévárenství - Izotermicky kalené litiny s kuličkovým grafitem. Praha: Český normalizační institut, ř́íen 1999.

[2] ČSN EN 14127: Nedestruktivní zkoušení - Měřeni tloušt'ky ultrazvukem. Praha: Český normalizační institut, červen 2011.

[3] KOPEC, B. a kol. (2008). Nedestruktivní zkoušení materiálů a konstrukcí. Brno: CERM, s.r.o., 2008. 582 s. ISBN 978-807204-591-4

[4] PODRÁBSKÝ, T., POSPÍŠILOVÁ, S. (2006.) Struktura a vlastnosti grafitických litin. Brno: VUT Brno, 2006. 54s.

[5] KRAUS, V. (2000). Tepelné zpracování a slinování. Plzeň: ZČU, 2000. 226 s. ISBN 80-7082-582-0.

[6] ŠENBERGER,J. (2003). Izotermicky kalená tvárná litina (ADI) - perspektivní materiál pro české slévárenství. Slévárenství - časopis pro slévárenský průmysl, 2003, roč. XLIX, č.11-12, ISSN 0037-6825.

[7] DORAZIL,E., VĚCHET,S., KOHOUT, J. (1998). Litina s kuličkovým grafitem a její vysokopecní varianta - ADI. Slévárenství - časopis pro slévárenský průmysl, 1998, roč. XLVI, č.11-12, ISSN 0037-6825.

[8] SKRBEK, B. (2004). Praktická aplikace ultrazvuku a magnetické zkoušky při výrobě litiny s kuličkovým grafitem. Spolupráca 2004: Mezinárodní konference slovenských, českých a polských slévárenských odborníků. Tatranská lomnica 2004. Sborník konference, s. 61-68.

[9] LECETA, J. J. (2009). New customer-supplier relationships and foundry technology developments. World Technical Forum: International Conference. Brno 2009. Conference Proceedings, p. 52-54.

[10] SKRBEK, B. (1988). Nedestruktivní materiálová diagnostika litinových odlitků. Liberec: VŠST Liberec, 1988. Disertační práce.

[11] BÍLEK, D. (2009). Parametrizace zařízení TELIT. Liberec: TUL, 2009. Diplomová práce.

[12] SKRBEK, B. (2006). Použití ultrazvuku k hodnocení kvality litinových odlitků. Slévárenství - časopis pro slévárenský průmysl, 2006, roč. LIV, č.9, ISSN 0037-6825.

[13] SKRBEK, B., TOMÁŠ, I. (2007). Magnetické lokální měření stavu zušlechtěné oceli. Metal 2007 : 16. mezinárodní konference metalurgie a materiálů. Ostrava: Tanger, 2007. Sborník konference, s.67-68, ISBN 978-80-86840-33-8.

[14] SKRBEK, B., TOMÁŠ, I., BÍLEK, D. (2011). Charakteristika oduhličení ocelových plechù. Hutnické listy, 2011, roč. 64, s. 27-31. ISSN 0018-8069.

[15] ADI applications [online]. 2012-09--- [cit. 2012-09-30]. Dostupné na WWW: http://www.aditreatments.com/?cat=4>. 